\title{
The role of local wisdom on the preservation of the Imogiri Royal Cemetery Site
}

\section{Peran kearifan lokal terhadap upaya pelestarian Situs Makam Imogiri}

\author{
Mimi Savitri \\ Department of Archaeology, Universitas Gadjah Mada \\ mimi.savitri@ugm.ac.id
}

\section{ABSTRAK}

Kata Kunci: Imogiri: makam rajaraja; manfaat; pelestarian; kearifan lokal
Situs Makam Imogiri telah memberikan manfaat bagi masyarakat sekitar khususnya para abdi dalem juru kunci makam Imogiri sejak dahulu. Para abdi dalem menciptakan kearifan lokal agar mereka dapat tetap bertahan hidup serta menikmati manfaat yang diberikan oleh situs tersebut. Pertanyaan yang diajukan adalah: Apa manfaat Situs Makam Imogiri bagi masyarakat sekitar khususnya abdi dalem juru kunci makam? Apa kearifan lokal yang diciptakan oleh para abdi dalem juru kunci Situs Makam Imogiri? Bagaimana peran kearifan lokal terhadap pelestarian Situs Makam Imogiri? Penelitian ini dilakukan untuk menguji sejauh mana peran kearifan lokal terhadap upaya pelestarian warisan budaya yang dilakukan para abdi dalem juru kunci makam untuk melestarikan Situs Makam Imogiri. Metode pengumpulan data penelitian ini dilakukan dengan cara in depth structure interview. Analisis dilakukan dengan menggunakan pendekatan interpretif. Interpretasi budaya dengan model hermeneutik digunakan untuk menjawab pertanyaan yang diajukan. Penelitian ini menghasilkan pengetahuan bahwa kearifan lokal berupa seni kriya batik, keris, wedang uwuh, cerita rakyat, dan upacara ritual Nawu Enceh, Kirab Budaya Ngarak Siwur, dan Nyadran Kraton telah ikut mendukung upaya pelestarian Situs Makam Imogiri secara aktif. Hal ini penting untuk menjaga keberlangsungan manfaat situs tersebut serta meningkatkan kesejahteraan masyarakat.

\section{ABSTRACT}

Keywords Imogiri; royal cemetery; benefit; preservation; local wisdom

The Imogiri Royal Cemetery Site has provided benefits to the surrounding community, especially abdi dalem as the caretakers of the site for a long time. The local community has created local wisdom in order to survive and continue to enjoy the benefits provided by the site. The question arises are: What is the benefit of the Imogiri Royal Cemetery Site for the surrounding community especially abdi dalem? What kind of local wisdom is created by the abdi dalem at the Imogiri Royal Cemetery Site? What is the role of local wisdom in the preservation of the Imogiri Royal Cemetery Site? This research was conducted to examine the role of local wisdom to preserve the Imogiri Royal Cemetery Site. The data collected using in depth-structure interviews. The analysis was carried out using an interpretive method with hermeneutic model of cultural interpretation. This research generates knowledge that local wisdom has contributed to the preservation of the Imogiri Cemetery Site. This is important to maintain the sustainability of the site's benefits and to improve people's welfare.

\begin{tabular}{|c|c|c|c|}
\hline 悬 & & $\begin{array}{l}\text { VOLUME } \\
\text { DOI } \\
\text { VERSION } \\
\text { WEBSITE }\end{array}$ & $\begin{array}{l}: 41 \text { No.1, Mei 2021,69-88 } \\
: \text { 10.30883/jba.v4li1.567 } \\
: \text { English (translated) } \\
: \text { berkalaarkeologi.kemdikbud.go.id }\end{array}$ \\
\hline ISSN: 0216-1419 & E-ISSN: 2548-7132 & & $\begin{array}{l}\text { This work is licensed under a Creative Commons Attribution-Non } \\
\text { Commercial-ShareAlike 4.0 International License }\end{array}$ \\
\hline
\end{tabular}




\section{INTRODUCTION}

The Imogiri Royal Cemetery Site located in Wukirsari Village, Imogiri District, Bantul Regency, Special Region of Yogyakarta is a complex of tombs of the kings of Islamic Mataram. The Imogiri Royal Cemetery is special because it was built by Sultan Agung, the greatest Mataram king and Indonesian National Hero who had bravely attacked the Dutch in Batavia in 1628-1629 (Graaf, 1986, pp. 150-157). Another distinction of the Imogiri Royal Cemetery site is that the people who are buried, were the sultans of Yogyakarta Sultanate Palace and the sunans of Surakarta Sunanate Palace. The two palaces still survive and exist to this day.

The notability of Imogiri Royal Cemetery Site as the tombs of the great kings of Islamic Mataram in Java attracted researchers to write about the archaeological remains of the site. H.J.de Graaf described this site as a complex of tombs of the kings of Islamic Mataram which not only consists of tombs, but other buildings or structures such as cungkups, gates, kelirs, stairs, and mosques (Graaf, 1986). The diversity and beauty of art in the buildings on the site attracted Hesus Lota to write a book on the architectural privileges of the buildings at the Imogiri Royal Cemetery Site which is a blend of Hindu-Buddhist and Islamic cultural influences (Lota, 1993). Hindu-Buddhist culture is seen in building ornaments such as antefixes, reliefs, and gates. The influence of Islamic culture is evident in the existence of mosques and tombs on the site. The writings of these experts confirm the particularity of Imogiri Royal Cemetery Site as the only tomb of Islamic kings from two major kingdoms in Java built with complete components on the top of the hill. This hill is known as Merak Hill, but people know it better as Imogiri or Pajimatan.

The notability of Imogiri Royal Cemetery Site in terms of the buried figure, Sultan Agung, the diversity of buildings and structures located at the top of Merak Hill, as well as the splendor and beauty of its gates have attracted archaeologists to preserve the buildings and tombs there. Wahyu Astuti, staff of the Regional Office for Cultural Properties Preservation, conducted a research related to the rescue efforts of the Imogiri Royal Cemetery Site which was damaged by the great earthquake that occurred on May 27, 2006 (Astuti, 2006). Other experts conducted a historical research of the buried figures as well as the architecture of the site. Saujana tourism development efforts or landscapes at the Imogiri Royal Cemetery Site and its surroundings are themes that attract experts to research the site (Rani et al., 2018).

Another interesting point of this Imogiri Royal Cemetery Site is that it was the first place to develop social, economic, and cultural life in Imogiri. Babad Nitiksarta Cabolek and folklore implicitly state that the place designated by Sultan Agung as his Cemetery ground was originally an uninhabited forest. The construction of tombs for Sultan Agung and the kings of Islamic Mataram who are descendants of Sultan Agung caused the Sultan Agung's abdi dalem to participate in building the Cemetery and maintaining the Imogiri Cemetery site.

Life around Imogiri Royal Cemetery then developed into a city now known as Imogiri City. This is evidenced by the existence of archaeological remains spread around the Imogiri Cemetery Site such as the Cemetery complex of the elites of Mataram Palace located in Giriloyo, Banyusumurup, and Singosaren. Other archaeological remains in Imogiri include ancient buildings, ancient structures, and village toponyms in Imogiri City.

Imogiri City is now the capital of Imogiri District. The similarity of the name of hamlets, cities, and districts with the name of Imogiri Royal Cemetery confirms 
the important role of Imogiri Royal Cemetery as the forerunner of the formation of a more complex culture, that is, Imogiri City. The area of Imogiri as a district is $54.49 \mathrm{~km} 2$ with a population in 2018 of 63,446 people. The area of land where Imogiri Cemetery Site is located is Pajimatan Hamlet and Banyusumurup Hamlet is $37.88 \mathrm{ha}$. The land area is not very large compared to rice fields in other villages (BPS Kabupaten Bantul, 2019).

The Imogiri Royal Cemetery site has long been known for its sacredness. For example, Sunan Pakubuwana VI from Surakarta Palace in the early 19th century had made a pilgrimage to the Imogiri Royal Cemetery (Heins, 2004, p. 72). The pilgrimage was done in order to ask for strength, because Sunan Pakubuwana at that time was known as the king of Surakarta Sunanate Palace who was persistent against the Dutch. Another example, Sumijati Atmosudiro, who was an eyewitness to the earthquake in Imogiri, said that at the time of the earthquake in 2006, people around Imogiri Royal Cemetery flocked to the Imogiri Royal Cemetery to ask for protection and tranquility from Sultan Agung. The earthquake that occurred in 2006 was a great earthquake which was unexpected by the people of Imogiri at that time (Sudrajat, 2016). The Javanese believe that the spirits of ancestors can be asked for blessings and protection for their safety (Adiansyah, 2017; Herusatoto, 2008; Savitri, 2015, 2016).

The community around Imogiri Royal Cemetery as mentioned above consists of the general people as well as abdi dalem as Cemetery site caretakers who live in villages around the Imogiri Royal Cemetery Site such as Wukirsari Village, Girirejo Village, and Karangtalun Village. This research was only conducted on the abdi dalem as caretakers of Imogiri Royal Cemetery, because their lives and activities are strongly related to the Imogiri Royal Cemetery Site. The three villages are located in Imogiri District.

The Imogiri Royal Cemetery Site has been providing great benefits for the surrounding community, especially the abdi dalem as caretakers of Imogiri Royal Cemetery Site. One of the benefits of the Imogiri Cemetery Site they felt is the water coming from the Imogiri Royal Cemetery Site. Mbah Warto, the owner of Warung Sederhana in Imogiri City, stated that the taste of his tea is famous among his enthusiasts not because of the tea leaves, but because of the water that comes from the Imogiri Royal Cemetery Site. The water that comes from the Imogiri Royal Cemetery Site, based on folklore, comes from Bengkung springs that come out by the blow of cis or Sultan Agung's cane. The water is flowed from the Imogiri Royal Cemetery Site down to Imogiri City.

The privileges and benefits of the Imogiri Cemetery Site for the abdi dalem as Cemetery site caretakers have inspired the creation of certain skills such as batik and kris making to maintain the existence of the site. Such efforts can be referred to as local wisdom. Local wisdom is a human effort with the ability to act and behave towards something, an object, or event that happens in a particular region. Local wisdom emerged as a process of evolution between the local community and the surrounding environment (Ridwan, 2007). Local wisdom in Imogiri emerged as a result of the efforts of the abdi dalem as Cemetery site caretakers to maintain the benefits they gained from the Imogiri Royal Cemetery Site and its important value since long ago until now. It is important to know this as a form of conservation efforts carried out by the abdi dalem as Cemetery site caretakers who live around the Imogiri Royal Cemetery Site.

The definition of Preservation is contained in the Law of the Republic of Indonesia No. 11 of 2010 concerning Cultural Conservation in Article 1 Paragraph 22. Paragraph 22 of the Cultural Conservation Law states that Preservation is "the 
dynamic program to maintain the existence of Cultural Conservation and its value". The way to implement Preservation is to protect, develop, and utilize it. Effort to protect or Protection is defined by the Law of the Republic of Indonesia No. 11 of 2010 on Cultural Conservation in Article 1 Paragraph 23. The paragraph states Protection as "the program to prevent and overcome from the damage, destruction, or obliteration by Salvation, Safeguarding, Zoning, Maintenance, and Restoration of Cultural Conservation". In connection with this, research on local wisdom of abdi dalem as Cemetery site caretakers is important to show their active and dynamic role in efforts to preserve cultural heritage. The maintenance of Cultural Conservation carried out by the abdi dalem has been in accordance with the Law on Cultural Conservation No. 11 of 2010 Article 75 on the Maintenance of Cultural Conservation by the community.

Imogiri Royal Cemetery Site is not just a passive and static historical site. On the contrary, Imogiri Royal Cemetery Site is a dynamic site that can mobilize people's lives, especially the abdi dalem as Cemetery caretakers in terms of social, economic, and cultural. A site is said to be dynamic when it can benefit the lives of the surrounding community (Smith, 2006, p. 46). This potential is forgotten by researchers and this study pays attention to the dynamism of a site.

Related to the background of the research, the question is: What are the benefits obtained by the surrounding community, especially the abdi dalem as caretakers of the Imogiri Royal Cemetery Site? What form of local wisdom is created by the abdi dalem Cemetery caretakers in relation to the existence of Imogiri Royal Cemetery Site? What is the role of local wisdom on conservation efforts undertaken by the abdi dalem as Cemetery caretakers regarding the Imogiri Royal Cemetery Site?

\section{METHODS}

This research is an interpretive research conducted to explore the interaction between the abdi dalem as caretakers in charge of the Imogiri Royal Cemetery Site with the culture they created. In connection with this, qualitative data collection was conducted by holding interviews with several abdi dalem Cemetery caretakers, because this research is indeed focused on the lives of abdi dalem which is much related to the existence of Imogiri Royal Cemetery Site. The questions asked were related to their activities in safeguarding and maintaining the tombs of the kings, as well as the benefits they gained from the tomb. Interviews used unstructured interview methods with in-depth interview techniques. This technique is used because it is considered to be able to retrieve more information from informants (Denzin \& Lincolin, 2007, p. 507).

Interviews were conducted in 2016 and 2017 on abdi dalem as caretakers of Imogiri Royal Cemetery Site both guarding the tombs of the kings of Yogyakarta and Surakarta. Interviews were also conducted to the bupatis of Imogiri Royal Cemetery Site, both based in Puroloyo and Kangjengan. These bupatis were leaders of the abdi dalem as caretakers of Imogiri Royal Cemetery Site. Puroloyo is the office of the abdi dalem caretakers of the tombs of the kings of Yogyakarta Sultanate, and Kanjengan is the office of the abdi dalem caretakers of the tombs of the kings of Surakarta Sunanate. Interviews to public figures such as Sumijati Atmosudiro were conducted to add information related to the Imogiri people's views on the Imogiri Royal Cemetery Site. Interviews with Bantul cultural observer Albertus Sartono were also conducted during data collection in the field. The interview was also addressed to Nani Nurhayati Lestari as a batik craftsperson and Sudarmaji as a kris master. The interview was conducted to get 
information about the association of the craftspeople with the Imogiri Royal Cemetery Site.

Another thing that was done during data collection was to observe the buildings, structures, and environments that exist at the Imogiri Royal Cemetery Site and around it. This observation was made because this research is related to the Cultural Conservation Site as a cultural landscape and the efforts to conserve it. Observations made in this study were not only conducted on tangible matters, but also intangible as well as the environment around the Imogiri Royal Cemetery Site.

Data collection in the form of books and articles related to this research was also conducted at an early stage. It is important to know the history of the construction of Imogiri Royal Cemetery Site as well as Javanese philosophy related to their belief in ancestors. Literature studies were needed related to Javanese people's view of things regarding the myth of the mountain as a sacred place.

The data collected was then analyzed using a cultural interpretation approach by applying a model of cultural or hermeneutic interpretation (Endraswara, 2012). The approach was used to understand the creativity of the people around Imogiri, especially those who became the abdi dalem Cemetery caretakers. This study seeks to 'read' and 'understood' cultural phenomenon and its meaning in relation to local wisdom as well as the preservation of the Imogiri Cultural Heritage Site. Further discussions were held to find out the extent to which local wisdom plays a role in the conservation efforts of the Imogiri Royal Cemetery Site.

\section{RESEARCH RESULTS}

\section{History of Imogiri Royal Cemetery Site}

The site of Imogiri Royal Cemetery located in Mount Merak was established by Sultan Agung for his own tomb (see Figure 1). Babad Alit states that the construction of Imogiri's tomb was handed over to Sultan Agung's uncle (Prawirawinarsa \& Djajengpranata, 1921). Another manuscript, Babad Momana states that the construction of the tomb, along with several gates built in Javanese Hindu architecture was completed in 1567 year of Dal, Javanese year or 1632 AD (Anonim, n.d., p. 18).

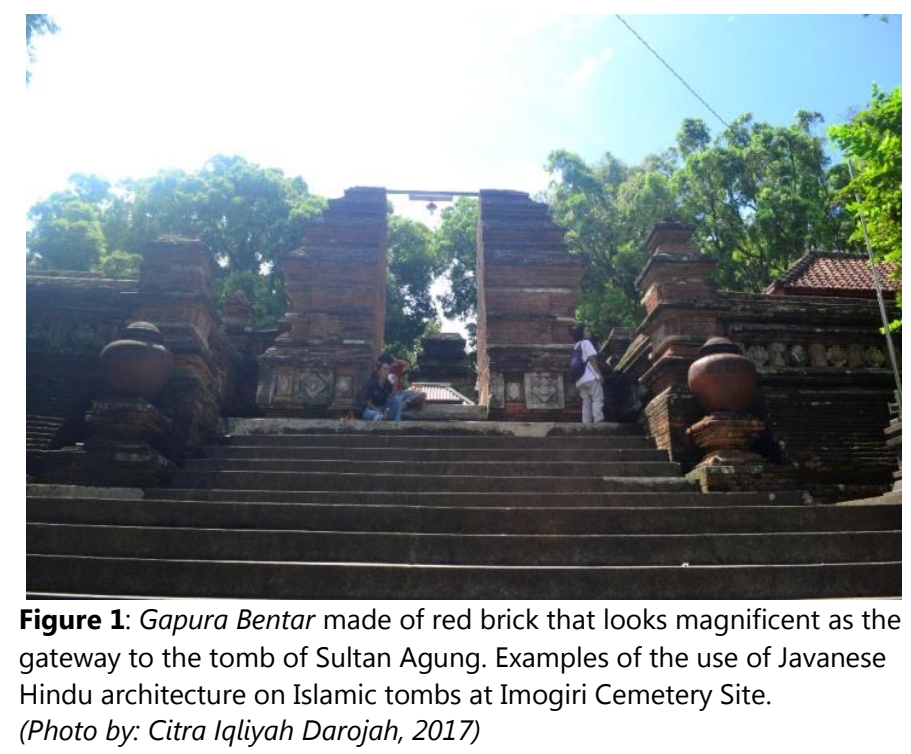


The Imogiri Royal Cemetery Site is better known to the local people as Pajimatan. The word 'pajimatan' comes from New Javanese language which means 'talisman place' or 'heirloom place'. A New Javanese text excerpt on this subject is found in the Babad Momana which is stated by "Angka 1567, tahun Dal, dadosipun Antakapura ing redi Merak, kaparingan nama ing Pajimatan" (Anonim,

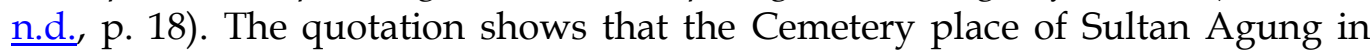
Mount Merak is believed to have magical and sacred powers. This can be said to be an intellectual construction formed to meet human needs for religious matters (Tuan, 1977, p. 100).

The story of the origin of Mount Merak as the Cemetery place of Sultan Agung is known from Babad Nitiksarta Cabolek (Wedhawati, 1980). The Babad or Javanese manuscript was written in 1941 or 300 years after the event. The manuscript, which was commissioned by Wedhawati in 1980, can be used as historical data, because the poet as the babad writer combines all his intellectual abilities gained from reading old and contemporaneous books (Sutjipto, 1977, p. 111).

The story written in the chronicle is known by the people of Imogiri until now. It shows that the story has become a tradition that is hereditary among the local community so that it can be called a folklore. Folklore is a shared culture of a society (Endraswara, 2012).

Babad Nitiksarta Cabolek recounts further, when Sultan Agung was doing his Friday prayers in Mecca, he spoke to Iman Supingi, the leader of the country, asking permission to be buried in Mecca. Iman Supingi refused on the grounds that Sultan Agung was of human and jinn descent, while those buried there were holy men. This caused the anger of Sultan Agung and with the help of his wife, Ratu Kidul (Queen of the South Sea), a plague was spread to the people of Mecca (Wedhawati, 1980, p. 132). Iman Supingi who felt he had caused the anger of Sultan Agung then asked Sunan Kalijaga to convey Iman Supingi's apology to Sultan Agung. Iman Supingi's apology was finally accepted by Sultan Agung and he asked Ratu Kidul who spread the plague to leave. The city of Mecca was then finally freed from disease.

Iman Supingi expressed his gratitude to Sultan Agung for saving the people of Mecca from the plague. Sultan Agung was then welcomed to choose the land to be used as a tomb for himself in the future and he chose a place with the prophets's tombs (Wedhawati, 1980, p. 133). Sunan Kalijaga who heard the answer of Sultan Agung who wanted to be buried near the prophet then said "Sultan, if you are buried here later, then who will be worshipped by your people. But you are the only one who deserves respect. If you want to be buried in the land of Mecca alone, it is easy. I will take a pile of earth from the tombs of the prophets, and I will toss it towards the land of Java. Follow the toss and it will certainly fall upon the land of Java". Sultan Agung agreed, then Sunan Kalijaga took a pile of land, wrapped it with a handkerchief, and tossed it towards Java Island. Sultan Agung chased the tossed earth, followed by Sunan Kalijaga until it finally fell in Giriloyo. Sultan Agung was disappointed, because he could not occupy the place as his Cemetery place. The place was requested by the Sultan of Cirebon as his Cemetery place when he died (Wedhawati, 1980, p. 134). Sunan Kalijaga advised Sultan Agung to once again follow the direction of where the earth fell tossed by Sunan Kalijaga of Giriloyo. Sultan Agung pursued the toss followed by Sunan Kalijaga, to the place where it fell on the top of a mountain (Wedhawati, 1980, p. 135). 
The Javanese belief in the mountain as a sacred place has been widely recognized by experts. They believed that the mountain was home to gods, ancestors, and supernatural-related things so that it became a place for meditation to gain magical powers (Fraser-Lu, 1986, p. 52). The mountain is considered a special place, because of its height, compared to the surrounding area and close to the 'upper world' (Mangunwijaya, 2013, p. 134). The 'upper world' is meant to be where God or a god is. In this regard, the mountain is believed to have a special and sacred power (Bernbaum, 2006). The specialty and sacredness of Mount Merak is more than anything else around it. This is narrated in Babad Nitiksarta Cabolek as follows:

"Upon arrival at the fragrant place, Sultan Agung asked Sunan Kalijaga how to overcome the holy land, but it was dry with no water to drink and wash his hands and feet. Sunan Kalijaga then walked towards the east and stuck his cis (wooden cane) in the stone until it cracked and released water. Sunan Kalijaga then pulled his cis westwards, ascending to Merak Mountain" (Wedhawati, 1980, p. 135).

Based on the survey conducted, it is known that the water discharge is now called Bengkung spring. Water from the spring is flowed to the pond in front of the mosque at the Imogiri Royal Cemetery Site. The story of the origin of the selection of Imogiri as the Cemetery place of Sultan Agung as told in the manuscript of Babad Nitiksarta Cabolek literature is very inherent in the life of the surrounding community and becomes a symbol of the culture of the people around the Imogiri Royal Cemetery Site. Folklore has become a cultural symbol that eventually becomes the cultural identity of a society (Stephens \& Tiwari, 2015). Cultural identity is a marker of a society and it fosters a sense of pride and confidence of a society when associated with the greatness of their ancestors (Prajnawrdhi et al., 2015; Stephens \& Tiwari, 2015).

The Imogiri Royal Cemetery Site is not only used as a tomb for Sultan Agung, but also a tomb for the kings of Islamic Mataram from two major kingdoms in Java namely Surakarta Sunanate and Yogyakarta Sultanate. The kings of the two great kingdoms of Java are descendants of Sultan Agung. This reinforces the privilege of the Imogiri Royal Cemetery Site (see Figure 2).

The arrangement of the tombs at the Imogiri Royal Cemetery Site shows the position of the buried kings. For example, Sultan Agung's tomb is in the middle and highest among other tombs. This location shows the position of Sultan Agung as the highest-ranking king among the other kings of Islamic Mataram. The location of the tombs of the kings of Surakarta is in the western part and the location of the tombs of the kings of Yogyakarta in the east. The Sultanate of Yogyakarta chose the eastern part of Sultan Agung's tomb for their kings tombs because the sultans of Yogyakarta wanted to be considered older than the sunans from Surakarta in the west. It is in accordance with the belief of Javanese people who consider that the east is older than the west. This information was obtained from the caretaker of Yogyakarta Sultanate, Jogo Wasito. 


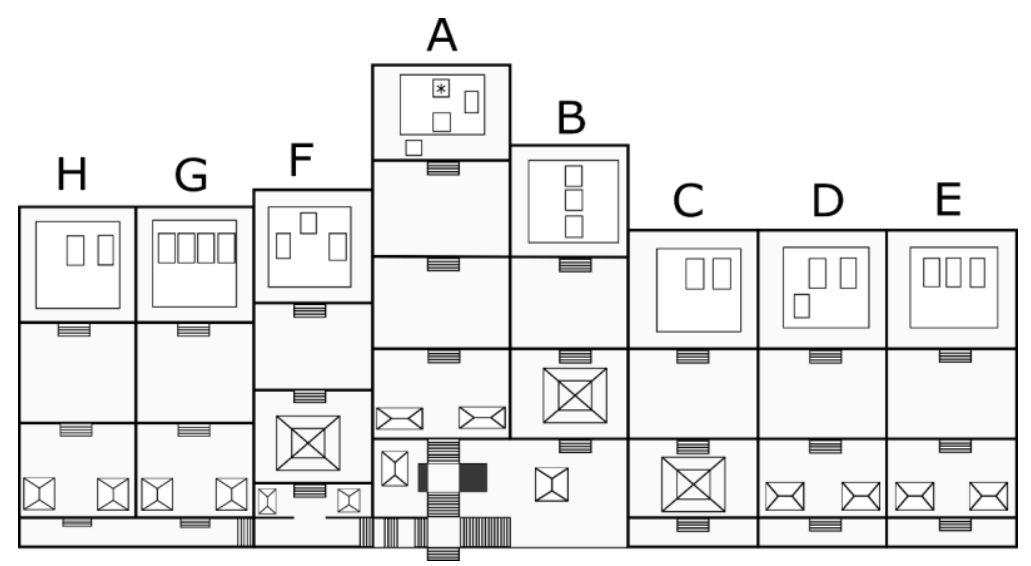

Figure 2: Imogiri tomb site plan.

(Source: Lota, 1993 re-drawn by Ainul Yaqin).

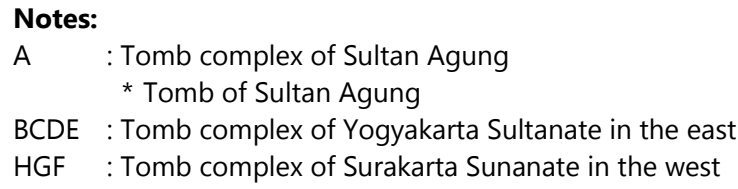

\section{Life of Imogiri People}

The life of the people around the Imogiri Royal Cemetery Site including the abdi dalem as caretakers of the site covers several aspects. Three important aspects related to this research are social, economic, and cultural.

\section{Social aspect: The arrival of Abdi dalem as Caretakers}

The life of Imogiri people has evolved since the beginning of the construction of Imogiri Royal Cemetery in Merak Mountain until now. The area was originally a forest unknown to people and later developed into a settlement by the arrival of the abdi dalem as caretakers of the Imogiri Royal Cemetery Site. They came to build and then maintained the tomb. The information was obtained from an interview with Jogo Wasito, an abdi dalem caretaker of Imogiri Royal Cemetery Site in charge of the tombs of the kings of Yogyakarta Sultanate. The information is confirmed by the story in Babad Nitiksarta Cabolek which mentions that Mount Merak which was discovered by Sultan Agung does not yet have a name (Wedhawati, 1980, p. 137). This indicates that the mountain was not inhabited by humans before the arrival of Sultan Agung.

Another folklore related to the naming of Merak Mountain was conveyed by Ari Purwanto, an employee of the Regional Office for Cultural Properties Preservation in D.I. Yogyakarta Province, who became the caretaker of Banyusumurup Cemetery. Ari Purwanto recounted that the name Merak Mountain was given by Sultan Agung who saw peacocks passing by, when he sat on a rock to rest, while chasing the earth tossed from Giriloyo. This explanation confirms that there was no human life in Merak Mountain when Sultan Agung chose the place as his Cemetery place later.

Life in Merak Mountain and its surroundings was getting more crowded and developed with the construction of the Cemetery site on the mountain. This is evidenced by the expanding area inhabited, not only at the foot of Merak Mountain and in Giriloyo alone, but to the surrounding area that is now the city of Imogiri District. The interview with Kanjeng Bupati Balad Jogokusumo recounted the existence of pesanggrahan and old markets in the city of Imogiri District. The Chinese also formed their own village near the old market. Their 
village is mentioned in a map issued in 1932 as Chin. Camp. The 1944 map has shown the existence of various professions living in the city of Imogiri District such as animal slaughterhouses, agricultural tools blacksmiths, potters, and embroiderers (Sumartono, 2019, p. 24). Toponym villages in Imogiri area such as Jagalan, Pandeyan, Kunden, and Sulaman prove the development of life from Merak Mountain to the surrounding area (see Figure 3 ).

The development of life that started from Merak Mountain is also seen in the construction of the offices of the abdi dalem caretakers of the Cemetery site in the city of Imogiri District. The office was named Puroloyo and Kanjengan. Puroloyo located in Wukirsari Village is the office of the abdi dalem caretakers of Yogyakarta palace and their leader, Kanjeng Bupati Hastonegoro. Kanjengan also located in Wukirsari Village is the office of the abdi dalem caretakers of Surakarta Palace. The head of Kanjengan's office is Kanjeng Bupati Rekso Suryo Hasmoro. The head of the abdi dalem caretakers of Cemetery Site ordered his subordinate abdi dalem who served as kliwon panewu as well as the mantri caretaker to maintain the security and order of the king's tomb. Babad Alit tells that the abdi dalem caretakers of this site have a schedule of guarding it alternately, every Monday at 07.00-09.00 and Friday 13.00-14.00. The abdi dalem were tasked with cleaning the site and sending flowers and incense.

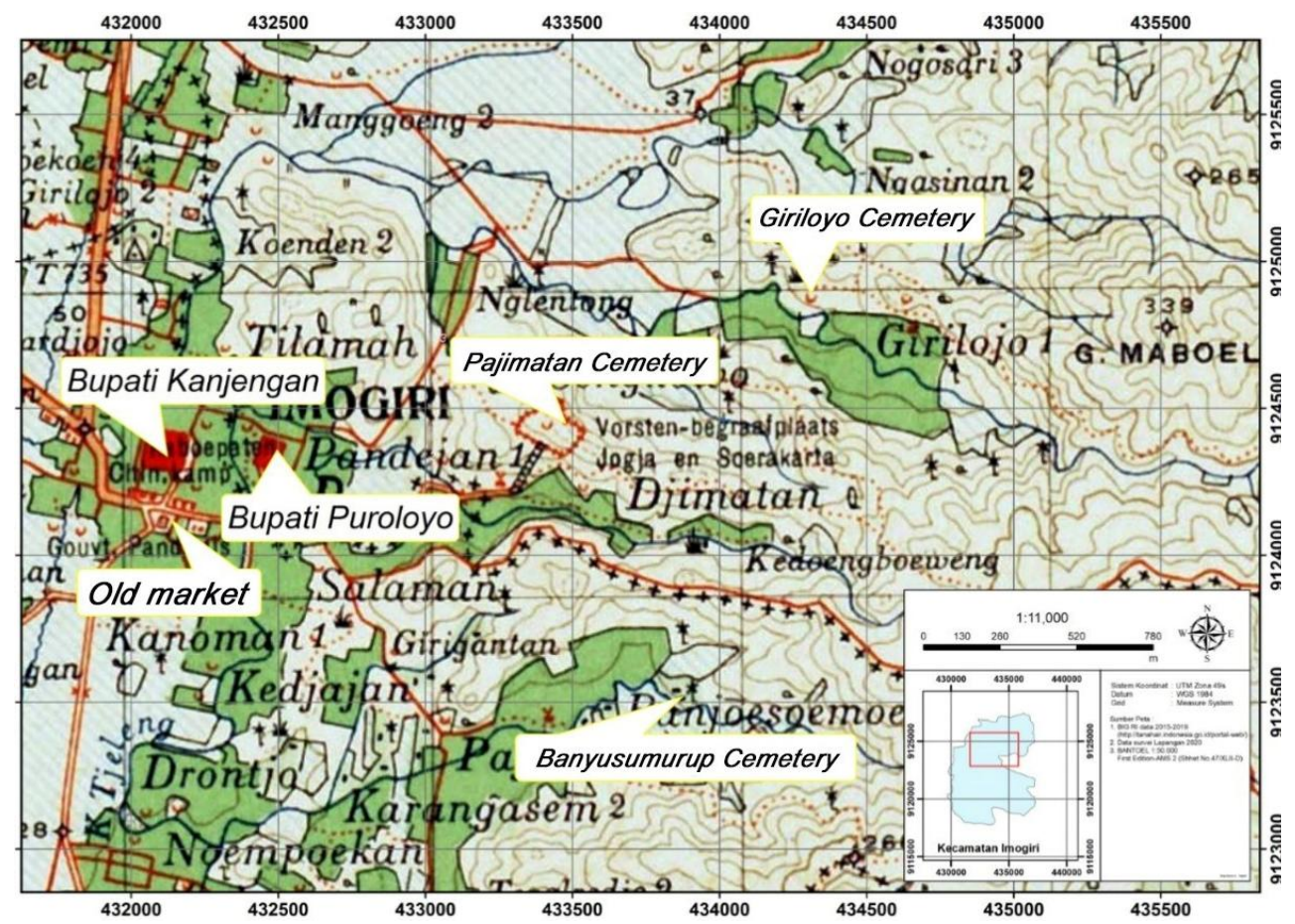

Figure 3: Imogiri city toponym map in 1944

(Source: http://tanahair.indonesia.go.id/portal-web/accessed 13 October 2020)

\section{Economic Aspects: Local Potential Development}

The abdi dalem caretakers of Imogiri Royal Cemetery Site have an important role in the economic life of the Imogiri area. Based on interviews with the caretakers of Imogiri Royal Cemetery Site, Jogo Wasito, it is known that the abdi dalem caretakers of the site initially received a salary in the form of land given by the palace to them. The land owned by the abdi dalem was used for farming, when they were not on guard duty of the tombs of Imogiri or Pajimatan, as well as the tombs of other royal families located in Imogiri District such as the tombs of Giriloyo, Banyusumurup, and Singosaren. Singosaren is the name of mataram 
royal family Cemetery complex which is also in the maintenance of abdi dalem Imogiri Cemetery caretakers. This less popular tomb is located in a lower place than the tombs of other kings in the Imogiri region. The social status of the person buried there is indicated by the location of the multilevel tomb. The higher the location of a person's tomb, the higher the social status of the person buried there.

Not all the land given to them was fertile soil, some of the land in the Imogiri region is infertile, because it mixes with limestone. Rice and crops produced were not sufficient for their needs. The condition did not detract from the intention of the abdi dalem caretakers of Imogiri tomb to remain devoted to their ancestors who were buried in the Imogiri tomb complex. They try to meet the needs of life by batik-making, a craft art passed down to their descendants to this day.

Another craft art was developed later, in the early 20th century in the Imogiri region, namely kris-making. Sosromenggolo, an abdi dalem caretaker of the site, developed the art of kris craft in his village which was then followed by his neighbors. Another potential development from the Imogiri Royal Cemetery Site today is wedang uwuh. This wedang or drink is believed to be invented after the completion of the construction of the tomb of Sultan Agung. The following is an explanation of the potential of the Imogiri community.

1. Batik

Batik handicrafts are found in two villages where the abdi dalem Cemetery Site caretakers live, Pajimatan and Giriloyo. Nani Nurhayati Lestari, the manager of Berkah Lestari Giriloyo batik group, and Jogo Wasito, abdi dalem caretaker of the Imogiri Royal Cemetery Site of Yogyakarta Sultanate, informed that at first batik-making skills were introduced by the abdi dalem who became caretakers of the Cemetery Site and their wives. Batik has been used by the abdi dalem since long ago and these abdi dalem and their wives make batik to meet their needs.

Batik making skills were then taught from generation to generation. Based on information obtained from Nani Nurhayati Lestari, it is known that her greatgrandmother who lived in the early 20th century was known as a batik maker during her time. KRT Jimat Pringgo Wadisumo, an abdi dalem caretaker of Imogiri Royal Cemetery Site who was interviewed at the Kanjengan Bupati's office, gave information that his mother and grandmother who became the wives of abdi dalem caretakers of Imogiri Cemetery Site were batik-makers. The art of batik-making is still known not only among the wives of abdi dalem, but also publicly. The batikmakers still preserve classic batik motifs in addition to making contemporary batik to order.

\section{Kris}

Kris is a craft art that appeared in Imogiri at a time earlier than batik crafts, which was around the beginning of the 20th century. Information about the famous kris making business in Imogiri comes from Banyusumurup village. This village is also known as the village where the abdi dalem caretakers of the site live in apart from Pajimatan and Giriloyo villages. Sudarmaji, the kris master and grandson of the founder of Banyusumurup village kris business in the interview said that the first effort to make kris in his village was developed by his grandfather named Sosromenggolo, an abdi dalem who was the caretaker of Pajimatan Cemetery site. Sosromenggolo with his skills to make kris involves the neighbors who among them are abdi dalem caretakers of the Cemetery site. The business of making kris in Banyusumurup village then developed rapidly until finally this village became famous for its kris crafts until now. 
3. Wedang uwuh

Wedang uwuh was developed by the people who live around the Imogiri Tomb Site. Jogo Wasito stated that wedang uwuh is a body-warming drink, a result of the development of body warmer drinks that have been known since ancient times after the Imogiri Cemetery Site was built. This drink is believed to be used as a cold medicine (Izdiha, 2019, p. 60). Initially, this drink was made from dried clove leaves that fell in the Imogiri Cemetery complex. The leaves were piled up like garbage when the Cemetery complex was being swept, which gave the drink using the basic ingredients of dried clove leaves the name 'wedang $u w u h$ '. The word 'wedang' comes from Javanese language which means 'drink', and ' $u w u h$ ' comes from Javanese language which means 'garbage', thus the name was given because the appearance of wedang uwuh resembles leaf litter (Izdiha, 2019, p. 61). Clove plants have been widely planted in the cemetery complex and its surroundings since long ago. The toponym of Cengkehan in Wukirsari Village proves the existence of cloves in the past. The contents of wedang uwuh developed by adding spices such as nutmeg, manis jangan or cinnamon, ginger, and sugar cubes as found today. Secang (sappan wood) is also added to wedang uwuh as red coloring.

\section{Rituals at Imogiri Royal Cemetery Site}

There are three rituals performed at the Imogiri Tomb Site, which are Nawu Enceh, Ngarak Siwur Cultural Parade, and Nyadran Kraton. The explanation of each ritual is conveyed as follows:

\section{Nawu Enceh}

Nawu Enceh is a ceremony to dispose of barrel water with the aim of cleaning the barrels in front of the tomb of Sultan Agung. Albertus Sartono, a Bantul cultural observer who writes a lot about Bantul culture, said that this ceremony or ritual was performed every Sura Month on Kliwon Friday since the mid-20th century. The event begins with a prayer reading by the Cemetery site's caretaker. Prayers are offered to God, the occult rulers of the tombs, as well as the ancestors buried in there. Ancestors and subtle spirits located in certain places or sacred places such as mountains or tombs by the Javanese are considered to have a special supernatural power. They must remain worshipped and respected in order to bring them salvation.

\section{Ngarak Siwur Cultural Parade}

Ngarak Siwur Cultural Parade is a ritual related to Nawu Enceh ritual that was first held around the early 21st century. The cultural ceremony was organized to complete the Nawu Enceh ritual with the aim of developing local culture and tourism. Imogiri Royal Cemetery Site is ranked 3rd in Bantul tourist destination (BPS Kabupaten Bantul, 2019). Local Government has an important role to develop this culture. The Regent of Bantul was actively involved when the Ngarak Siwur Cultural Parade was implemented. The participation of the regent and the local government shows that the culture is not static but dynamic because it can be developed in accordance with time by all elements of society. Ngarak Siwur Cultural Parade is performed before Nawu Enceh ritual which is on Wage Thursday in the afternoon with a route from Imogiri District to the Imogiri or Pajimatan Royal Cemetery Site (see Figure 4). 


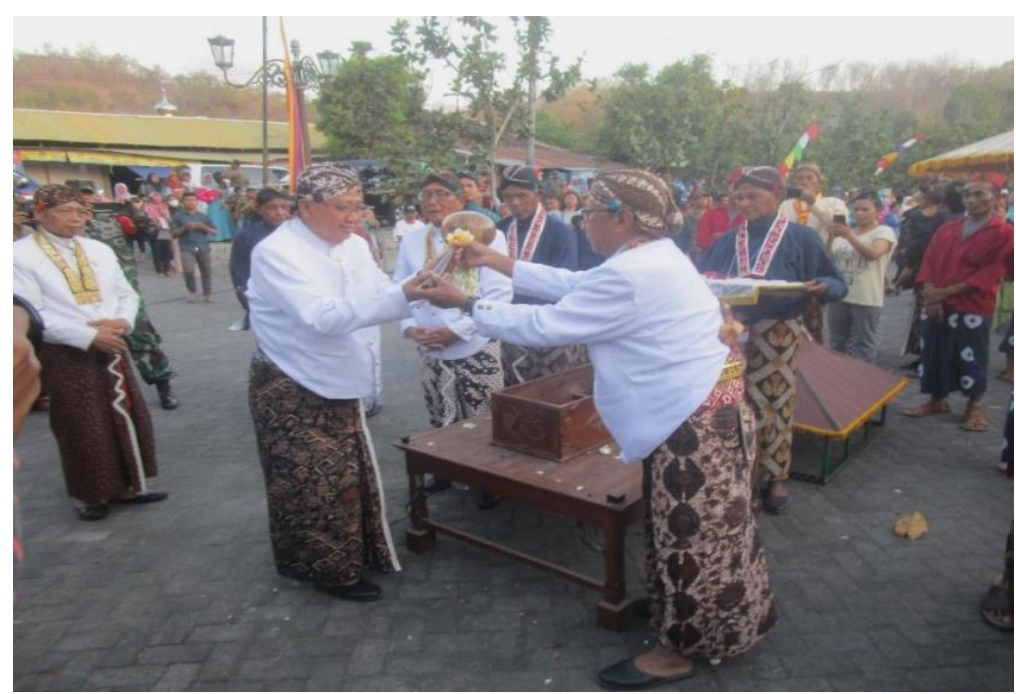

Figure 4: Handover of Siwur from Bantul Regent to the Head of Cemetery Guard Office, Kangjeng Bupati, during Ngarak Siwur Cultural Parade. The Siwur would be paraded at Ngarak Siwur Cultural Parade in Imogiri.

(Photo taken by: Albertus Sartono)

\section{Nyadran Kraton}

Another ritual performed at the Imogiri or Pajimatan Royal Cemetery Site is Nyadran Kraton which is performed during the month of Ruwah at Pendapa Supit Urang. Kanjeng Bupati Balad Jogokusumo who was interviewed stated that the tradition in Ruwah month was done to honor the ancestors. This ritual is also performed in other tombs around Imogiri tombs such as Giriloyo, Banyusumurup, and Singosaren.

\section{Imogiri Royal Cemetery Site and Its Benefits for the Surrounding Community}

The current cultural heritage development concept is different from the concept described earlier by the experts. Experts have previously stated that cultural heritage is a magnificent building or site that stands alone, unrelated to the existence of other archaeological dwellings, neighborhoods, and surrounding communities. Experts today consider that buildings or sites of cultural heritage cannot be separated from their context because they are within the context of a system that is still ongoing today (Tanudirjo, 2003, p. 5). The statement is in accordance with a new paradigm for the study of cultural heritage contextualized with people's lives (Ashmore \& Knapp, 1999, p. 1).

The context of cultural heritage can be in the form of archaeological remains that exist around the cultural heritage or the environment around it. This includes the community surrounding the cultural heritage that interacts with it. With this understanding, the research on Imogiri Royal Cemetery Site as a cultural heritage is not treated as a stand-alone site, but related to the environment and the surrounding community, especially the abdi dalem caretakers.

Most of the people around Imogiri Royal Cemetery Site are those who feel the benefits of the existence of cultural heritage. The benefits provided by cultural heritage to the surrounding community can be material or non-material (Aplin, 2002 , pp. 16-17). Material and non-material benefits are also enjoyed by the community around the Imogiri Royal Cemetery Site including the abdi dalem Cemetery caretakers who interact intensively at the site. Research on the benefits of cultural heritage for the community is considered important because the knowledge of the benefits of cultural heritage in society indirectly shows the 
significance or important value of cultural heritage for the community (Spradley, 1979 , p. 27).

The material benefits of cultural heritage are usually associated with the increasing economy of the community. The improvement of the economic sector in the community around cultural heritage is mostly obtained from the tourism sector (Rani et al., 2018). Tourism that makes cultural heritage as a tourist destination is called heritage tourism or cultural heritage tourism (Bonotan \& Lee, 2010). Expert studies related to heritage tourism among others state that a large number of visitors to the cultural heritage will benefit the community in terms of economy (Amir et al., 2015; Aznar \& Hoefnagels, 2019; Campelo et al., 2018; Prajnawrdhi et al., 2015).

The economic benefits have further impact on the preservation of cultural heritage. Cultural heritage becomes more preserved and maintained because cultural heritage can guarantee their well-being. This is also the case at the Imogiri Cemetery Site. When many tourists come to Imogiri Cemetery Site to go on cultural heritage tours, pilgrimage tours, and tours to see Ngarak Siwur cultural parade followed by Nguras Enceh ritual ceremony, it will provide benefits for the community in terms of economy.

Another advantage with heritage tourism is the visit of tourists to other attractions located around the cultural heritage. For example, visitors to Imogiri Royal Cemetery Site will continue their journey to visit batik craftspeople's villages in Girilaya Village or Pajimatan Village located at the foot of Merak Mountain. If they are interested in kris, they will come to Banyusumurup Village where the kris craftspeople are after visiting Imogiri Royal Cemetery Site. The arrival of these tourists has undeniably improved the economy of the surrounding community including the abdi dalem caretakers of Imogiri Royal Cemetery Site (Suwarjo, 2019).

Another benefit provided by the Imogiri Royal Cemetery Site is the nonmaterial benefit. The benefit is a sense of tranquillity within the community. For example, Jogo Wasito recounted, one day he had no money, when there were financial matters to be resolved. He was upset because he did not have money, suddenly came a pilgrim who gave him money. The money was received with pleasure because it helped to settle his financial affairs and he increasingly believed that being the abdi dalem of Pajimatan or Imogiri's Royal Cemetery Site brought blessings and peace of mind.

The blessed feeling is another benefit obtained by the abdi dalem caretakers of Imogiri Royal Cemetery Site. Jogo Wasito stated that despite the nominal value of the salary or honorarium they earned as abdi dalem caretakers of the Cemetery site was small, he felt blessed because he could meet all the needs of his life. The role of his wife who trades and makes batik also appeases him because their needs suffice in terms of material.

Another abdi dalem, Fajar Reksoko, stated that his great-grandfather had been the abdi dalem caretaker of the Imogiri Royal Cemetery Site for a long time. Fajar Reksoko further explained that being abdi dalem caretaker of the Cemetery site was an important work, because it determines their position, status, and existence. Not only that, being an abdi dalem caretakers of Imogiri Royal Cemetery Site also have an impact towards the increase of their economy.

Budi Lumak, another Imogiri Royal Cemetery Site abdi dalem caretaker, gave a similar statement to the information provided by Fajar Reksoko. He stated that being the abdi dalem of the Imogiri Royal Cemetery Site was a prestige or pride for him because they could become priyayi or people with a higher degree of social 
class than the general public.

Recognition in the form of a high degree in the community is another noneconomic benefit obtained by the abdi dalem caretakers of Imogiri Royal Cemetery Site. This was because of the words of Sultan Agung. KRT Jimat Pringgo Wadisumo, an abdi dalem caretaker of Imogiri Royal Cemetery Site from Surakarta Sunanate stated, Sultan Agung once said that the wong cilik (small people) of Pajimatan Imogiri should be respected, because Pajimatan is a talisman or heirloom for them. People from Pajimatan village located at the foot of Merak Mountain including the abdi dalem caretakers of Pajimatan or Imogiri Cemetery Sites were looked up to by people from other villages because they were considered as heirloom keepers.

Jogo Wasito in the interview stated unequivocally that the people around the Imogiri Royal Cemetery Site felt being a part of the site. The sense of belonging to the Imogiri Royal Cemetery Site is immense in all layers of the Imogiri community, whether they are a family of abdi dalem, sellers, craftspeople, and the general public. The society's high sense of belonging emerged because the Imogiri Royal Cemetery Site is the tomb of the kings of Islamic Mataram as well as their ancestors and pepundhen. It also raises the pride of the community towards the Imogiri Royal Cemetery Site and reinforces the identity of the surrounding community.

The benefits as well as the important value obtained by the people of Imogiri, especially the abdi dalem caretakers of the site as stated above of course should to be maintained. The abdi dalem tried hard to stay and maintain the Imogiri Royal Cemetery Site as an ancestral heritage, even though their lives were in a difficult situation. This encouraged the emergence of creative efforts such as batik and kris craft art in Imogiri. Wedang uwuh developed today is also a form of creativity or can even be referred to as a form of local wisdom of the Imogiri community including the abdi dalem caretakers of the Cemetery site.

\section{DISCUSSION}

Local wisdom has several definitions presented by experts. First, local wisdom is defined as a device of knowledge in the community that comes from previous generations or from the experience of today's society related to the environment and other communities to solve problems and/or difficulties faced (Ahimsa-Putra, 2019, p. 34). Local wisdom is also defined as all efforts or actions taken by local communities to overcome problems faced wisely (Njatrijani, 2018, p. 18). What needs to be underlined from the two definitions above is that, first, local wisdom is a knowledge created to solve problems and/or difficulties faced in a long time. Second, local wisdom can be created in the past and present. It shows that local wisdom can be a cross-generational creation or tradition, but it can also be an innovation based on people's experience in dealing with the environment they wherein (Utama, 2013). Another intresting definition is when local wisdom is widely interpreted, local wisdom is not only in the form of cultural norms and values, but also all elements of ideas including those that implicate technology (Sarwono, 2016).

Based on the definition that has been conveyed, folk crafts created such as batik and kris making, wedang uwuh, folklore memorized by Imogiri people, as well as the implementation of ritual ceremonies Nguras Enceh, Ngarak Siwur Cultural Parade and Nyadran Kraton, can be said as a form of local wisdom created by the community around the Imogiri Royal Cemetery Site including the abdi dalem caretakers of the site. The efforts of the abdi dalem caretakers of the site and 
their wives and descendants can be categorized as an effort to overcome the problems faced. The two problems faced by the abdi dalem caretakers of Imogiri Royal Cemetery Site are infertile land as well as small salaries. They use batik and kris making technology to be able to survive living in infertile soils, but have a cultural heritage that provides great benefits for them both materially and nonmaterially. Craft art making technology that has been developed such as batik, kris, Nguras Enceh ceremony, Ngarak Siwur Cultural Parade, and Nyadran Kraton is a local wisdom created by the abdi dalem.

Local wisdom to make wedang uwuh is a proof of the intellectual and skill of the community around the Imogiri Royal Cemetery Site. They managed to make use of the natural resources in the Imogiri Royal Cemetery Site to make a drink that can be used as a cold medicine and sold, thus increasing income for the household of the abdi dalem caretakers of Imogiri Royal Cemetery Site.

Another example of local wisdom can be seen in the community's efforts to preserve folklore about the construction of Imogiri Royal Cemetery Site by Sultan Agung. The story known by the Imogiri community for generations is a local wisdom based on cultural values, because it has formed an attachment between the surrounding communities including the abdi dalem Cemetery site caretakers with the Imogiri Royal Cemetery Site. The story that was passed down through generations has risen the people's emotions in the form of pride in the power of Sultan Agung. Pride can arise because of people's emotional attachment to their place and cultural landscape (Cotter et al., 2001, p. 3). The attachment of emotions needs to be maintained so that the surrounding community, which is partly the abdi dalem of Imogiri Royal Cemetery Site, can preserve their cultural heritage. Such efforts are important to maintain the continuity of the benefits of the Imogiri Royal Cemetery Site to the surrounding community including the abdi dalem caretakers of the site.

Other types of local wisdom are in the form of the implementation of Ngarak Siwur Cultural Parade, Nguras Enceh ritual ceremony, and Nyadran Kraton. The implementation of the ritual is not only an effort to preserve the existence of Imogiri Royal Cemetery Site and its traditions, but also to maintain the continuity of the livelihood of the abdi dalem Imogiri Royal Cemetery Site caretakers and the people who live around the Site. The ritual activities are new, but still related to the existence of ancestors and the beliefs of the community around the Imogiri Royal Cemetery Site. It is a form of sustainable preservation of cultural heritage (Kealiikanakaoleohaililani et al., 2018). When associated with the theory of system context, it can be perceived as an attempt to give new meaning, but it remains in the existing system context (Tanudirjo, 2003).

The description of various forms of local wisdom as it has been stated, shows how local wisdom has played a role in the conservation efforts of Imogiri Royal Cemetery Site conducted by the surrounding community, especially those who work as abdi dalem caretakers of Imogiri Royal Cemetery Site. Things done by the community related to the conservation efforts of Imogiri Royal Cemetery Site has contributed to maintaining the continuity of the livelihood of the surrounding community, especially the abdi dalem Cemetery site caretakers in terms of economy. The local wisdom that developed in Imogiri does not show Imogiri Royal Cemetery Site as a passive cultural heritage site, but a dynamic one. Imogiri Royal Cemetery Site has inspired the surrounding community to act creatively in various forms to support the preservation efforts of Imogiri Royal Cemetery Site. 


\section{CONCLUSION}

Imogiri Royal Cemetery Site, as a Cultural Conservation Site has a privilege in terms of history and architecture. This site has provided both material and nonmaterial benefits to the surrounding community including the abdi dalem caretakers of the Cemetery site. The benefits provided by the Imogiri Royal Cemetery Site are very meaningful for the surrounding community including $a b d i$ dalem caretakers of Imogiri Royal Cemetery Site. The benefits and important value of Imogiri Royal Cemetery Site have formed the emotional attachment of the surrounding community including the abdi dalem to stay around the Imogiri Cemetery site even though the natural environment conditions do not support growing good crops, or a small amount of salary. Abdi dalem caretakers of Imogiri Royal Cemetery Site who live around the tomb and their wives then developed forms of creativity in the field of technology such as batik-making, kris-making, and wedang uwuh, as well as cultural values such as folklore and ritual ceremonies as a form of local wisdom.

All of that was developed by the abdi dalem Cemetery site caretakers and impacted on the sustainability of the Imogiri Royal Cemetery Site. The preservation of Imogiri Royal Cemetery Site can be maintained both physically and culturally. This confirms that cultural heritage is dynamic and can affect the lives of the surrounding community.

Forms of local wisdom that have been created and developed by the Imogiri community, especially the abdi dalem Cemetery site caretakers have been an important asset for the preservation of Imogiri Royal Cemetery Site in the future. If it is managed together between the community and the government, efforts to preserve the Imogiri Royal Cemetery Site can be achieved even better and this of course has an impact on the increasing benefits provided by the Imogiri Royal Cemetery Site in the future.

\section{AUTHOR DECLARATION}

The author contributed to the creation of this manuscript. The author has read and approved the manuscript. The author received research funding in 2017 from Faculty of Cultural Sciences, Universitas Gadjah Mada for the creation of this manuscript. The author confirms that there are no known conflicts of interest associated with this publication and there has been no significant financial support for this work that could have influenced its outcome. The author adhered to the Copyright Notice set by Berkala Arkeologi.

\section{ACKNOWLEDGEMENT}

Thank you to Prof. Dr. Sumijati A.S. for the inspiration and input given to this article especially related to the lives of Imogiri people. The author also thanks Prof. Dr. Inajati Adrisijanti and Drs. Albertus Sartono for their inputs related to Imogiri Royal Cemetery Site and the lives of the surrounding community. Last but not least, the author thanks the Faculty of Cultural Sciences, Universitas Gadjah Mada, for the funding in 2017 for this research about the Imogiri Royal Cemetery Site. 


\section{REFERENCES}

Adiansyah, R. (2017). Persimpangan antara agama dan budaya (proses akulturasi Islam dengan slametan dalam budaya Jawa). Jurnal Intelektualita: Keislaman, Sosial Dan Sains, 6(2), 295-310. https://doi.org/10.19109/intelektualita.v6i2.1612

Ahimsa-Putra, H. S. (2019). Bahasa, sastra, dan kearifan lokal di Indonesia. Mabasan, 3(1), 30-57. https:// doi.org/10.26499/mab.v3i1.115

Amir, S., Osman, M. M., Bachok, S., \& Ibrahim, M. (2015). Sustaining local community economy through tourism: Melaka UNESCO World Heritage City. Procedia Environmental Sciences, 28, 443-452. https://doi.org/10.1016/j.proenv.2015.07.054

Anonim. (n.d.). Babad Momana. Koleksi Badan Penerbit Soemodidjojo Mahadewa.

Aplin, G. (2002). Heritage: identification, conservation, and management. Oxford University Press.

Ashmore, W., \& Knapp, A. B. (Eds.). (1999). Archaeologies of landscape: contemporary perspective. Blackwell.

Astuti, W. (2006). Studi teknis kompleks makam Imogiri tahap I. Balai Pelestarian Cagar Budaya D.I. Yogyakarta.

Aznar, M., \& Hoefnagels, H. (2019). Empowering small rural communities through heritage tourism. In Delivering Tourism Intelligence (pp. 49-60). Emerald Publishing Ltd. https://doi.org/10.1108/S2042$\underline{144320190000011005}$

Bernbaum, E. (2006). Sacred mountains: themes and teachings. Mountain Research and Development, 26(4), 304-309. https://doi.org/10.1659/02764741(2006)26[304:smtat]2.0.co;2

Bonotan, G., \& Lee, E. (Eds.). (2010). Perspectives on heritage tourism. SEAMEOSPAFA.

BPS Kabupaten Bantul. (2019). Kecamatan Imogiri dalam angka 2019. BPS Kabupaten Bantul.

Campelo, A., Reynolds, L., Lindgreen, A., \& Beverland, M. (2018). Cultural heritage (A. Campelo, L. Reynolds, A. Lindgreen, \& M. Beverland (Eds.)). Routledge. https://doi.org/10.4324/9781315107264

Cotter, M., Boyd, B., \& Gardiner, J. (2001). Understanding communities: valuing place, an introduction. In M. Cotter, B. Boyd, \& J. Gardiner (Eds.), Heritage Landscape: Understanding Place and Communities (pp. 335-336). Southern Cross University Press.

Denzin, N. K., \& Lincolin, Y. S. (2007). Handbook of qualitative research. Pustaka Pelajar.

Endraswara, S. (2012). Metodologi penelitian kebudayaan. Gadjah Mada University Press.

Fraser-Lu, S. (1986). Indonesian batik processes, patterns and places. Oxford University Press.

Graaf, D. H. J. de. (1986). Puncak kekuasaan mataram. Pustaka Grafiti Pers.

Heins, M. (2004). Karaton Surakarta. Yayasan Pawiyatan Kabudayan Karaton Surakarta. 
Herusatoto, B. (2008). Simbolisme Jawa. Ombak.

Izdiha, A. (2019). Wedang uwuh, daya pikat cita rasa lokal. Mayangkara, 8, 60-61. Kealiikanakaoleohaililani, K., Kurashima, N., Francisco, K., Giardina, C., Louis, R., McMillen, H., Asing, C., Asing, K., Block, T., Browning, M., Camara, K., Camara, L., Dudley, M., Frazier, M., Gomes, N., Gordon, A., Gordon, M., Heu, L., Irvine, A., ... Yogi, D. (2018). Ritual + sustainability science? a portal into the science of aloha. Sustainability, 10(10), 3478. https://doi.org/10.3390/su10103478

Lota, H. (1993). Album pasareyan raja-raja Mataram.

Mangunwijaya, Y. B. (2013). Wastu Citra. PT Gramedia Pustaka Utama.

Njatrijani, R. (2018). Kearifan lokal dalam perspektif budaya kota Semarang. Gema Keadilan, 5(1), 16-31.

Prajnawrdhi, T. A., Karuppannan, S., \& Sivam, A. (2015). Preserving cultural heritage of Denpasar: local community perspectives. Procedia Environmental Sciences, 28, 557-566. https://doi.org/10.1016/j.proenv.2015.07.066

Prawirawinarsa, R., \& Djajengpranata, R. (1921). Babad Alit. Volkslectuur.

Rani, F. P., Kusuma, H. E., \& Ardhyanto, A. (2018). Pariwisata pusaka: destinasi dan motivasi wisata di pusaka saujana Imogiri Yogyakarta. Jurnal Planologi, 15(2), 149-163. https:// doi.org/10.30659/jpsa.v15i2.3524

Ridwan, N. A. (2007). Landasan keilmuan kearifan lokal. Ibda', 5(1), 27-38.

Sarwono. (2016). Mapping and protecting the intellectual property right in the field of the traditional batik design of tirtomoyo as the cultural heritage and its development based on the local genius in the creative industrial era. Yustisia Jurnal Hukum, 5(3), 622-642. https://doi.org/10.20961/yustisia.v96i0.5020

Savitri, M. (2015). Peran magis-religius Bengawan Solo dalam pendirian kota Surakarta abad ke-18. Kalpataru, 24(1), 37-46. https://doi.org/10.24832/kpt.v24i1.59

Savitri, M. (2016). Landscape transformation: from Sala village to the capital of Mataram kingdom. Spafa Conference.

Smith, L. (2006). Uses of heritage. Routledge. https://doi.org/10.4324/9780203602263

Spradley, J. P. (1979). The ethnographic interview. Waveland Press.

Stephens, J., \& Tiwari, R. (2015). Symbolic estates: community identity and empowerment through heritage. International Journal of Heritage Studies, 21(1), 99-114. https://doi.org/10.1080/13527258.2014.914964

Sudrajat, S. W. (2016). Pemahaman tentang menejemen bencana alam siswa sekolah menengah pertama. Jipsindo, 3(2), 168-189. https://doi.org/10.21831/jipsindo.v3i2.11697

Sumartono, D. A. (2019). Catatan silam pajimatan Imogiri. Mayangkara, 8, 22-25.

Sutjipto, F. A. (1977). Unsur sejarah dalam sastra sejarah. Buletin Fakultas Sastra Dan Kebudayaan, 5, 111-120.

Suwarjo. (2019). Community based tourism dalam pengelolaan desa wisata Giriloyo, Wukirsari, Imogiri, Bantul. Populika, 7(1), 66-80. https://doi.org/10.37631/populika.v7i1.28

Tanudirjo, D. A. (2003). Warisan budaya untuk semua: arah kebijakan 
pengelolaan warisan budaya Indonesia di masa mendatang. Makalah Disampaikan Pada Kongres Kebudayaan V, Bukittinggi, 19-23.

Tuan, Y.-F. (1977). Space and place, the perspective of experience. Edward Arnold.

Utama, B. (2013). Bertani dengan arif: pertanian organik sebagai alternatif mewujudkan kedaulatan pangan. In E. J. M. Prioharyono (Ed.), Kearifan Lokal \& Lingkungan (pp. 61-78). Pusat Penelitian dan Pengembangan Kebudayaan, Kementerian Pendidikan dan Kebudayaan.

Wedhawati. (1980). Babad Nitik sarta Cabolek Kanjeng Sinuwun Sultan Agung ing Mataram. Balai Bahasa. 
This page was left intentionally blank. 